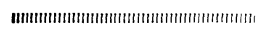

講 座 LECTURE

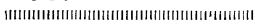

\title{
粉体材料の基礎的性質の測定 (V)*
}

\author{
（粉体材料の付着・凝集性とその測定）
}

神 保 元 二**

\section{1 緒 \\ $1 \cdot 1$ 粉体材料の付着凝集}

粉体の性質や挙動がさまざまな粒子の物性によって 影響され決定されることはいらまでもないが，最近と くにその物性の中でも, いわゆる付着・凝集特性が注 目され, 研究も多く, 測定方法の考案・開発も盛んで ある. しかし付着・凝集特性と一口にいっても, その 内容はきわめて基礎的なものから, 充てん性, 流動性, 浮遊性のような実際の操作と関連した複合的な性質ま で，きわめて広汎のものを含んでいる。

しかし，一般に付着力というと，最近ではかなり基 礎的な一次的物性を示するのとされてきているようで 西る。 その定義については，付着 (Adhesion) とは異 種物質の粒子間, あるいは粒子一平面間の結合力であ って，同種粒子間，あるいは粒子一粒子間の結合にも とずく凝集（Cohesion）と区別すべきである，といら 考壳が一般的なようであるが，最近 Zimon は後者を 自己付着 (Autohesion) として付着と区別し，両者を 対比させてもっと分子的で表面が関与するミクロな特 性としての凝集 (Cohesion) を定義している。

筆者は粒子一平面の相互作用は, 粒子一粒子間の片 方の径が無限大の場合に当たると考光，この両者を区 別する必然性はないものと考光ている，同種，異種の 物質間の区別についても同様である。したがって筆者 はとりあえず付着力と凝集力を次のように定義して測 定法を展望することとしたい。す なわち付着力とは相接している 2 つの粒子あるいは粒子と平面を， 接触面に垂直な方向に引張って分 離するに要する力であり, 凝集力 とは 2 個以上の粒子が相互に付着 力を作用しあって集合体を形成し ている力である，後者は付着力を 主にしながら, 他の物理化学的現 象（たと党ば電気化学的）や，付 着力に対比さるべき基本的な物性 值である摩擦特性など他の因子も

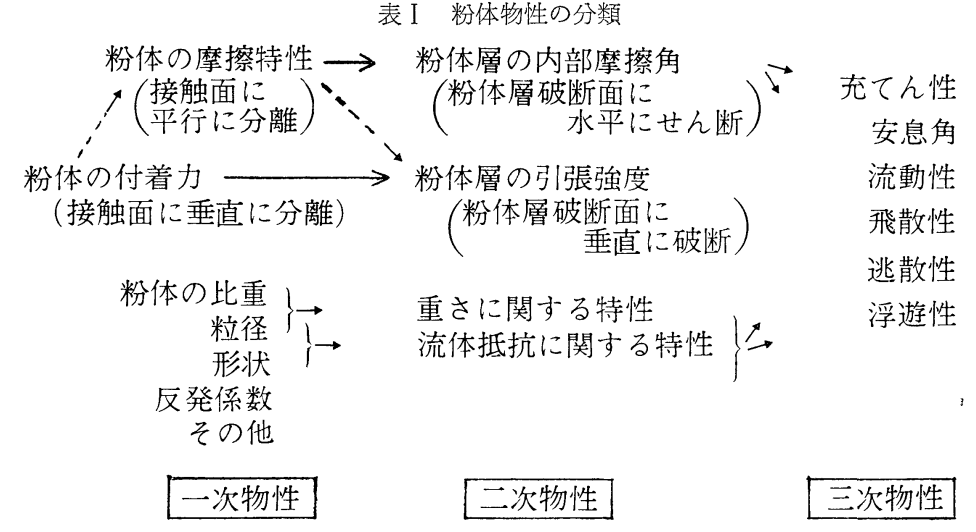

含めた複合体的な力である。このように考えることが， 現実の粉体工学の諸現象之対応した物性として適切な のではあるまいか.Zimonがいらもら少しミクロな現 象としての結合力は, また別考光ればいいと思う。

ここでは上記の粉体の付着・凝集現象の要因となっ ている力の測定について，とくに付着力に重点を执い て展望したい。

\section{2 粉体の付着・凝集特性の測定法}

粉体粒子, 岕るいは粉体層の特性や挙動を決定する 因子は複雑であるが, 粒子の大きさ (粒径), 形状, 比重などはもっとも基礎的なもので, これにさらに機 械的 (反発係数など), 電気的 (静電的など), 熱的性 質などがもっとも基礎的なるのとして考光られる。こ れらにくらべると若干複雑なものと思わ机るが，ここ で主題としている付着力拈よび次回で主題となるであ らら摩擦特性もこれらと同じレべルのものと考壳てよ からら。したがってこれを一次物性としたい。そして これらの物性が他との関連で一義的にあらわ机る（2 つの一次物性が複合的汇作用しない）物性として, 粉 体層としての性質や気流中での特性などを考光, これ を二次物性とする，このよう洘光ると，実際工業上 で問題となるいわ㠴る実用的測定法が求めようとして いる物性は, 一次物性, 二次物性が複雑にから反市。 てあらわれているものをみることができよら。したが ってこれを三次物性ということができよう。(表 I I)

表 I 粉体物性の分類

* 原稿受理 昭和 45 年 7 月 23日

** 正 会 員 名古屋大学工学部 名古屋市千種区不老町 
表 II 粉体物性測定法

\begin{tabular}{|c|c|c|c|c|}
\hline & 世一次物性 & 二次物性 & & 三次物性 一 \\
\hline 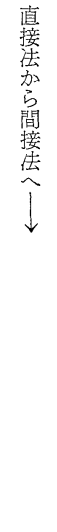 & $\begin{array}{l}\text { ○遠心分離佉・振動分離法 } \\
\text { ○スプリング・バランス法 } \\
\text { ○振子法 } \\
\end{array}$ & $\begin{array}{l}\text { ○引張破断去 } \\
\text { (高圧成型・低圧成形 }) \\
\text { ○直接女ん断法 } \\
\text { (一軸, 三軸, 一面, 二面 })\end{array}$ & 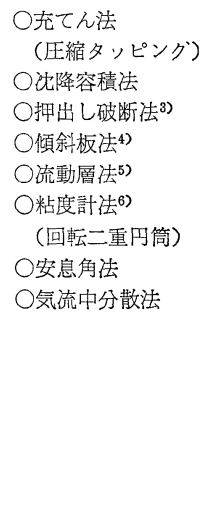 & $\begin{array}{l}\text { O付着板引き上げ法7) } \\
\text { OStrcknness 法8) } \\
\text { (流下排出法) } \\
\text { ODustability 法 } \\
\text { (Andreasen 発塵法) } \\
\text { ODirpersability 法9) } \\
\text { (分散法) } \\
\text { O浮遊性測定法10) } \\
\text { O逃散性法 } \\
\text { OFlow-tester 法12) } \\
\text { (Carr の方法) }\end{array}$ \\
\hline
\end{tabular}

（とこでは文献は国内のむののみに止めた．その他の文献については，筆者の他の解説を参照されたい）

ここでこのようなことをくだくだ述べたのは，付着 ・凝集性の測定法は広い測定対象を有して扣り，その 結果を相互に簡単に対応させたり比較したりすること は困難であること，そして各測定方法間の関連性は作 用している因子が単純なものから複雑なものへ，と考 察していくことによって見いだされると思われるから である。

次に各種の付着・凝集性測定法をこれらの点と関連 させて 1 つの表にまとめて示す.（表II）この分類と 位置づけは決して結論的なものではないが，1つの試 案としてみていただきたい。

そしてここではこの表でいって左上の部分にある方 法のみをとりあげ，必要に応じて他の方法にもふれる こととするが，ここでとりあげた以外の方法，とくに 摩擦特性々関係の大きいものは, 本連続講座の次回に とりあげられることと思う。

\section{1 個粒子の付着力の測定法}

付着力測定のらちもっとも基礎的なものは，1個の 粒子を他の粒子，あるいは平面から分離する方法であ ろう。すなわち，1個粒子・直接測定法である。この 方法はもともと物理学者が London-van der Waals 力の測定のために考案したものが多く, 多くの方法が 提案されているが, 現在実際に用いられているのは, 遠心分離法などごく限られている。

\section{$3 \cdot 1$ スプリング・バランス法（図 1，a）}

粒子を充分な弾性をもつスプリングまたはビームの 先端につけ, 接触面を動かすことによって引張力を生 じさせ, 畄性たわみより分離時の力を求める方法であ る.

\section{$3 \cdot 2$ 振子法 (図 $1, b$ )}

細線の先につけた 2 個の粒子，または粒子と平面を 接触させ，図のよらに細線の支持点をずらして徐々に
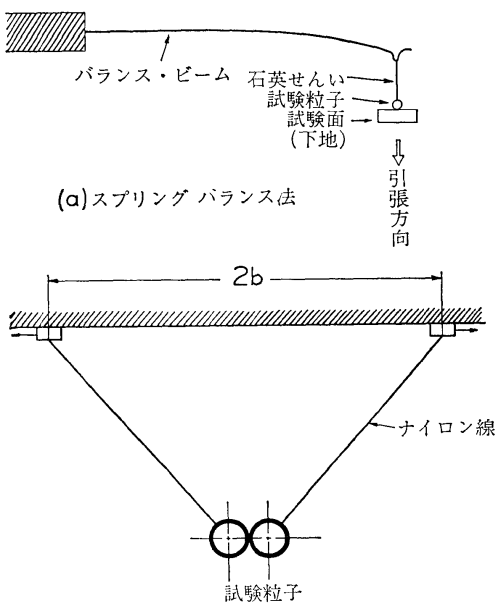

(b) 振子法 (Schubert)

図 11 個粒子の付着力測定法(1)

引張力を増加させていき, 分離点に和忷る振子の傾き 角度から付着力を計算する方法である.この方法はと くに特定の測定器其を必要とせず簡便な点に特長があ る.

以上の 2 つの方法は，かなり大きい，乙かも球形粒 子でないと測定が難しいという限界があるが，簡単に しかも粒子の状態を観察しながら, 測定が行なえると いう点で, 最近でもたとえば付着水分の毛管力の湘定 などに用いら机ているよらである。

\section{$3 \cdot 3$ 遠心分離法. 振動分離法}

上記の方法では粒子に直接引張力を加光るため粒径 に限界があるが，この点を解決するため，粒子自身の 質量を利用する方法として遠心分離法と振動分離法が ある。

$3 \cdot 3 \cdot 1$ 測定の概要 固体平面に粉体粒子を分散 


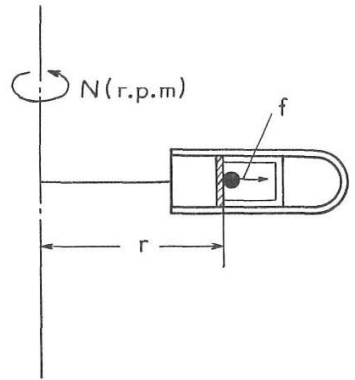

図 2 遠心分離法の原理

付着さ吼,この平面を遠心機中にセットして回忶させ， 粒子を遠心場に扔く。この場合径 $D_{p}$ の粒子に加わる 分離力 (=付着力) $f$ は次式で計算できる。

$$
f=\frac{\pi}{6} D_{p}^{3} \rho_{p} r(2 \pi N)^{2}
$$

振動を用いる場合も全く同様である。(図2)

一般には粒子は粒度分布定有するし，また均一粒径 であっても付着力そのものが分布を有する性質である から，fの值も分布を有する。乙たがって粒子を表面 に分散，付着した固体平面の写真を，遠心分離操作の 前後で撮影して，ある回転数 $N$ に対して実際に分離し た粒子を求めていく必要がある。この粒子の写真撮影 とそれから粒度分布を求める操作が，時間的にも学力 的にもこの方法の主要部となっている。

そして一般にはある分離力 $f$ に対して，その分離力 を受けた粒子のらら何パーセントが残留したか（ある いは分離したか）层求めて，分離残留率 $\varphi(\%)$ を求 め, これを分離力 $f$ に対してプロットして, 分離残留 率曲線の形で結果を整理するのが普通である。(図 4)

$3 \cdot 3 \cdot 2$ 測定手順上の問題 この方沠では固体表 面としては何をえらんでもいいわけであるが，表面の 円阶やあらさが大きく影響するから，再現性あるデー タをとるためには, 平滑な面, それも写真撮影の便か らいってガラスのような透明な物質の方が適当であろ う。しかし，遠心場としてかなり大きい力を作用させ ることも㐫るから，ガラスなどが破譬しないように気 をつける必要がある。

遠心機は特別なもので岁る必要はないが，一番の問 題は測定七ルの温度が上昇することである。このため ふん柬気の温度が変化する恐れがある。一般に10２0 $\mu$ 以下くらいの微粉の付着力测定では, 相当回転数を 上げる必要があるので，温度上昇に対する対策のこう じてある遠心機を用いることが望ましい。

次に遠心操作前後の分敞付着粒子の测定に関してで あるが、これについては影像計数法（顕微鏡法）の粒 度测定と同様に考えればよい。しかし，さらに順々に 粒子が分離していく過程を測定するには，篻者らの用
いているネガ・ポジ法が有用であろう。この方法は遠 心前後の写真のいずれかを反転し（カルバーフィルム を用いると非常に簡単にできる)，この2つを重和合 わせると残留粒子は白黒逆のものが重なって像が消え てしまい，分離した粒子だけが黒く浮きだしてくる。 (図 3）このような方法で測定の手間は非常に省くこ とができる。
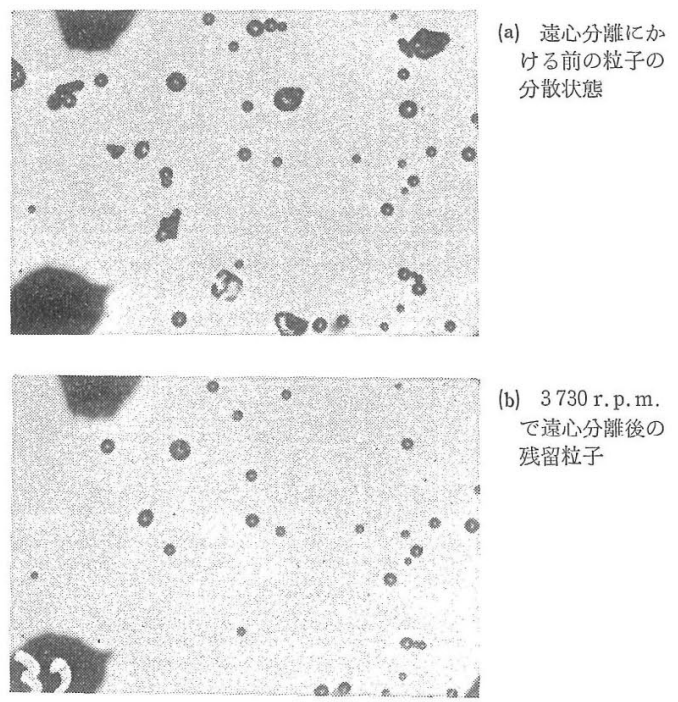

(b) 3730 r.p.m. で遠心分掊後の 残留粒子

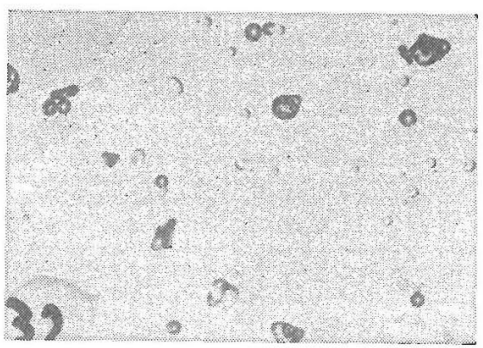

(c) 上の(b)の画面 を反転させて白 黑を逆にし(a)の 画面之重标あわ せたすの. 分剭 した粒子だけが 黒く浮きだして みえる

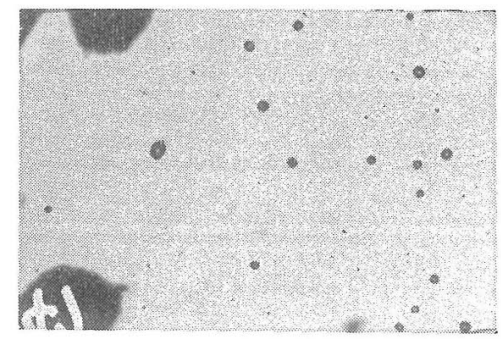

(d) さらに 4380 r.p.m. で橾心 分鹃した後に残 留した粒子

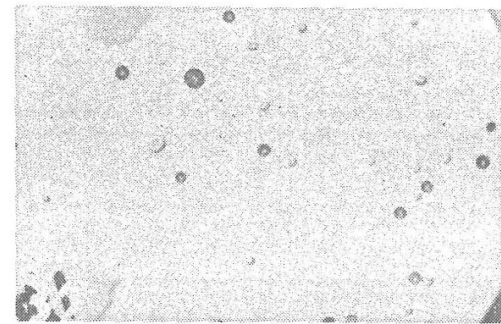

(e) (d)の画面を反 転させて白黑逆 とし, (b)の画面 と重ねあわせた むの. 同じく分 踓した粒子は黒 くみえている

図 3 遠心法の測定画面のネガーポジ法による処理実例 16 


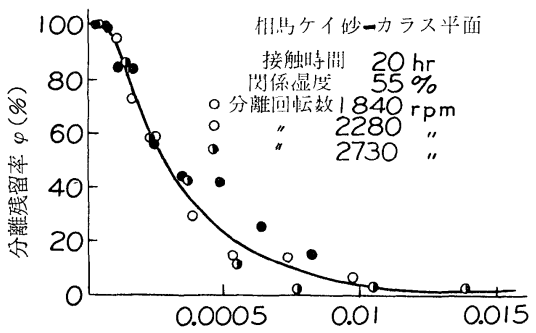

分離力 $=$ 付着力 $F$ (dyne)

(a) 贱川らの結果の 1 (例16)

カラ又球一銅半偭

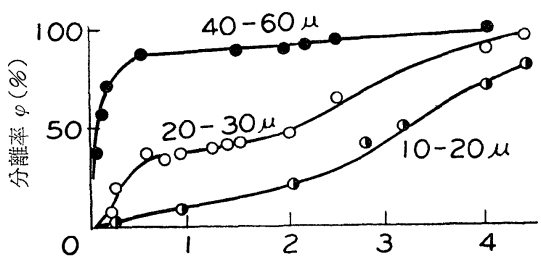

分 離 力 $f(g)$

(b) Z Imon らの結果の 1 例1)

図 4 遠心分離法による粒子残留分離率曲線 扣よび分離率曲線

$3 \cdot 3 \cdot 3$ 測定結果の評価 すでに述べたように付 着力は一種の確率的現象であって, 同一粒径, 同一状 態でも必らずあるバラッキをもっている，したがって 付着才は本来確率的な分布関数としてしかあらわせな い。これを図に示すと図 4 (a)(b)のよらになるが，ここ で分離残留率をとる（筆者ら，Krupp らの測定）か， 分離率をとる (Zimon) かは全くいずれでもかまわな い。この曲線から50\%分離の付着力とか，90\%残留， 90\%分離の付着力とかを定義して拈けばいいのである.

ここで注意を要するのは，この分布関数はかなり幅 が広いといらことである。ここで示した分布が一番狭 い筆者らの測定結果（図 4 (a)）でも，50\%分離力に対 して $99 \%$ 分離には数倍の力を要することがわかる。こ の場合, 遠心の回転数を変えて測定しても分離残留曲 線があまり変わらないので，その分布は粒径によるも のではなく付着力そのものに帰因するものであること がわかる。Zimon の結果（図 4 (b) ) をみるさらに 付着力の分布が大さい場合があることがわかる。した がって遠心法によって全粒子を分離するに要する力を もって付着力とするような考光は, 実際に難しいし, また詔差の大きいものとなるら。

な抗この分離残留曲線は一般に対数正規分布 $\varphi=100 \int_{0}^{\infty} \frac{1}{\sqrt{2 \pi} \log \sigma_{g}} \exp \left[-\frac{\left(\log f-\log f_{50}\right)^{2}}{2 \log ^{2} \sigma_{g}}\right] d(\log f)$ 16)

に從うことが浅川らによって見いだされている。この 関係は独立にZ Z imon らによっても発見されて招り, かなり広い条件下でなりたつと考えていいであろら。
したがって分離残留曲線は全域にわたって求める必要 はなく，(2)式より推定が可能であろう.

\section{$3 \cdot 4$ 吹き飛ばし法}

繊維充てん層の集塵などと関連した研究が行なわれ ているが，実際に繊維その他の細線に付着させてジェ ット気流で吹きとばす方法と，遠心法などと同様にガ ラス板上に分散付着させた粒子に水平方向から気流を 流して分離過程を測定するものがある。この場合に気 流の流速分布が正確にわかっていれば，粒子に加えら れた抵抗力から分離力二付着力が求められるわけであ るが，ここには摩擦特性も入いってくるであららから， 較密に一次物性としての付着力と考えていいかどらか 疑問がある。またCorn らは遠心法で粒子に加えられ る力の方向が，平面に対して平行になるようにして分 離力を求め，これを吹き飛ばし法の結果と比較してほ ぼ一致することを認めている。

\section{$4 \cdot 1$ 引張破断法}

4 粉体層の付着力の測定法

粉体層を形成し，その層を破断させて引張方向に直 角の破断面によって分離し，そのときの引張強度をも って付着力とする方法である。この测定方法もいくつ か報告されているが，打もなものをあげれば次のと和 りである。

(1) Rumpf-Turba の方法：粉体層を高压で成形し て試験棒をつくり，これを引張試験機にかけて破断す るものである，高压で成形するので成形時に粒子の破 砕を伴らことが考光られる。そこで测定後試験棒は液 中で分解して 1 個 1 個の粒子をばらばらにし，粒度分 布を测定している。当然粒度分布は広くなるわけで， 充てん状態にも影響を与えているであろら。いずれに しても Rumpf-Turba の測定結果は, 他の方法による 測定結果にくらべてかなり大きくでている.
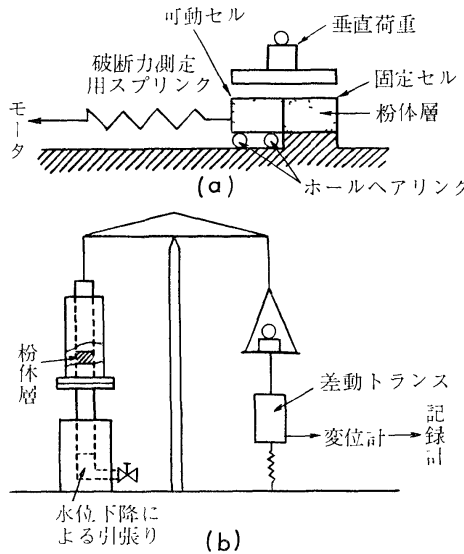

(a) Farley-Valentin 0引张独度任

(b)山川らのテンピン式引張強度佉

図 5 付着力測定法の例 


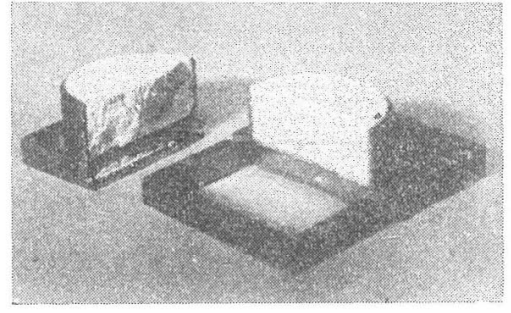

図 6 引張破断法による粉体層の破断 （右の部分がベースに固定されており， 左の部分がボールベアリング上にのって いて，引張りによって移怔したすのであ る. 写真はべースからはずしてばらばら にして破断面を示したもので弁る)

(2) Ashton-Farley-Valentin の年法: 粉体層学高さ の低い円筒状のセルの中で形成するが，このセルは真 中で 2 分割して片方が水平方向に自由に動忷るよらに なっている。（図5,(a)）これによって粉体層を引張 破断して（図 6) 付着力を求めるわけであるが，この オ法では Rumpf-Turba の方法のように強く成形する 必要がないので, 粉体の普通の推積状態に近い粉体層 の付着力を測定できる点に特徴がある。この装置は後 に述べるせん断試駼機と基本棈造が同じである点も特 徵といえよう。

この方法の引張力は図に示したよらにスプリングの 伸びからも求号れるが，やはり筆者らが用いている ようにストレン・メータで記録して求める方が正確で あろう。Shotton のように，このセルを㖽けていって 可動七ルが自重で破断作用走行ない，その傾斜角から 破断に要した付着ノを求好ようという簡便法も考学ら れているが, 余り推萀できない。

（3）田中らの方法：前述の方法は粉体層を成形する 加压方向と，破断の引張方向名一致していない点に 1 つの問題があるが，この点加压方向と引張方向を一致 さ吠た田中達夫らのテンビン式引張強度法は注目すべ さ点をもっている。（成５(b)）しかしこの方法による 测定結果はあまり発表されて拈らず，またあまり测定 方法として採用されていないよらである。

\section{$4 \cdot 2$ 引張破断法測定時の問題点}

粉体層の弓張強度は, 粉体層を形成するときの条件 によって大きく影響される。これはすず第一に粉体層 の空隙率にが異なり，その結果として粉体粒子間の接 虽点数 $N$ が変わってくるからである。引張破断強度 $\sigma_{z}$ と， $N$ おるよび 1 侗粒子の付着力 $f$ の間には次の Rumpfの式の関係がある, とされている。（ 配位数)

$$
\sigma_{z}=f N=\frac{9}{8} \frac{(1-\varepsilon)}{\pi d^{2}} k f \fallingdotseq 1.1 \frac{(1-\varepsilon)}{\varepsilon d^{2}} f
$$

したがって压密によって粉体層の空隙が減少するの

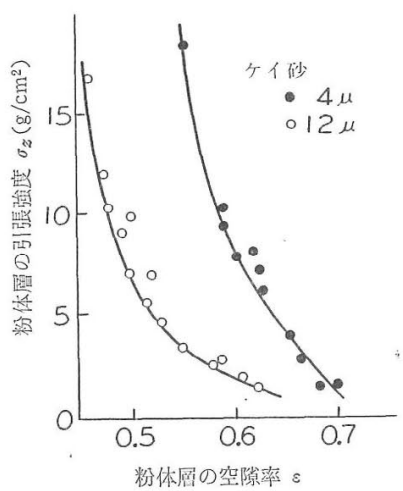

図7 粉体層の引張破断強度に及致す空吵率の影響25

に伴って，引張强度 $\sigma_{z}$ は增大し，これは測定結果と も一致する。（図 7 ）このため粒体層の引張強度（付 着力）は常に空吵率（ないしかさ比重）の関数形とし て示され，一義的な物性值としては求まらないことに なる。

そこで物性值としてはやはり1個粒子当たりの付着 力 $f$ をいることとし，(3)式岁るいは他の 係学用いて $\sigma_{z}$ より $f$ 㠻計算すれ独よい。 $\varepsilon \sim k$ の関 係についてい次の Ridgway らの式その他の関係が実 驞的に見いだされている。

$$
\varepsilon=1.07-0.119 k+0.00431 k^{2}
$$

したがって(3)式によって，(1-と)k に対して $\sigma_{z}$ 定プ ロットするのも 1 つの方法であって, その結果付着力 $f$ が直線のこら配として求められるはずである。とこ ろが図 8 に示したよらに $(1-\varepsilon) k \sim \sigma_{z}$ の関係は直線に ならず，付着力 $f$ の值は空吵率 $气 の$ 関数となる。した がってこの粉体層の付着力の測定絬果からそのまま 1 個䊀子の付着力を一義的に求めるわけにはいかない。 このように付着力 $f$ が空吵との関数となる原因につい ては粉体物性研究の子っとも中心的課題として现在議

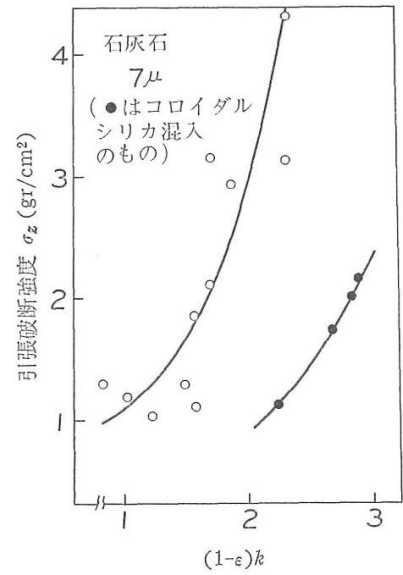

図 8 (1-8)kで整理した粉体層の付着力 
論のまととなっているわけであるが，測定法とは直接

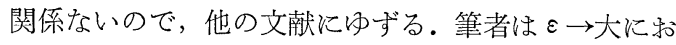
ける付着力 $f$ の值をもって 1 個粒子の付着力とするの が適当と考えているが，詳論は別な機会にゆずりたい。

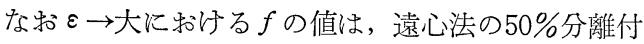
着力より大幅に下まわるのが普通である.

またこのほか粉体層形成時の条件（充てん条件）が 付着力の結果に影響を及ぼす。とく加圧充てん方式 とタッピング方式で大きい差があらわれる。また加圧 時間もある程度の影響があると考光るべきであろう。 破断力を作用させる引張速度も問題があるかも知れな いが，この点については筆者らは引張強度はストレン メータを用いているが，力の緩衡用としてスプリング む用いている。しかし後 2 者はそ机核ど重要な因子で はないようである。

\section{$4 \cdot 3$ 単純せん断法}

せん断法は図 9 のような装置によって粉体層の摩擦 係数 (とくに内部摩擦係数) を測定するものであって， その意味で付着力測定法としては全く副次的なもので ある. しかし周知の次の Coulomb の式

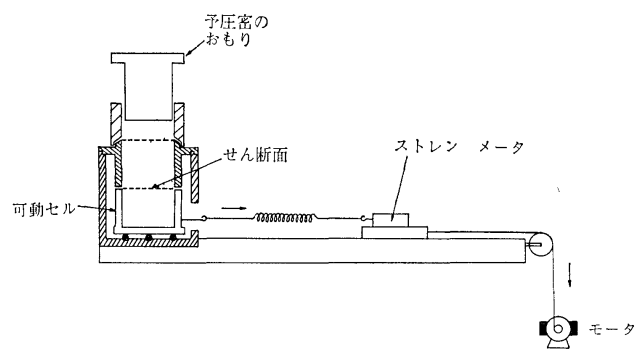

図 9 せん断試験装置

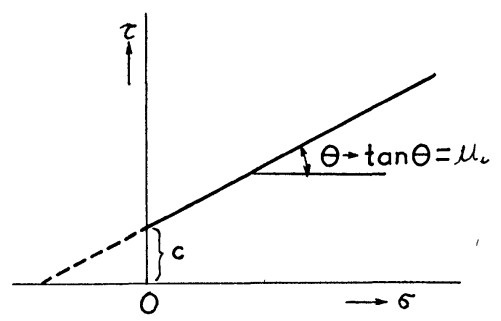

図10-(a) Coulomb の式の図示

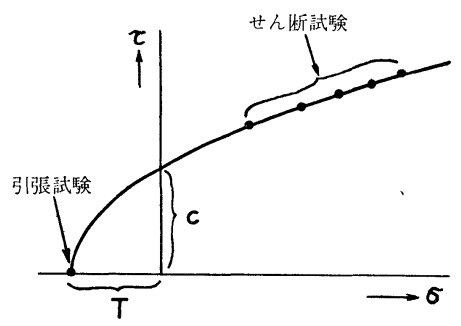

図10-(b) 付着力，粘着力を考光に入れた $\sigma \sim \tau$ の関係図

$$
\tau=\mu_{\imath} \sigma+C
$$

に沶いて，Cのい方ゆる粘着力が付着力と密接に関係 していると考兄らている. (図10，(a))

この点に関して最近 Ashton-Farley-Valentin の修 正式が提案されて括り, この関係式は広く認められて きているようである。

$$
\left(\frac{\tau}{C}\right)^{n}=1+\frac{\sigma}{T}
$$

この式では内部摩擦係数はそのままではとり入れられ ておらず, 指数 nの形になっているが, 粘着力 $C$ と引 張破断強度 $T$ が求まることになっている。（図10(b)) そしてCキTである。しかし現在むでの測定結果では， 引張破断強度 $\sigma_{z}$ 之せ九断試験の結果より(6)式を用い て求めた $T$ の值は一致せず, 一般に $T>\sigma_{z}$ といら結 果が觉られている。そして，Cの値は一般にさらに大

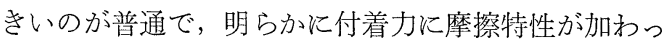
てみかけ上付着性を大きくしているものと考光られる。 つまりこの粘着性測定法は, 内部摩擦角測定之同一 装置で同時に測定できる凝集性測定方法という点に特 徵があるが, 一次物性でないことはもちろん, 二次物 性としてもな和問題がある，といえるであろう。な特 せん断試験装置と引張破断装置は, ごく一部を除いて ほとんど共通に使える部分からなっているから，基礎 的なデータを求める場合は, やはりなるべく引張付着 力と内部摩擦係数をそれぞれにできる限り正確に求め ることが望ましいと思われる。

\section{5 結言}

以上粉体物性測定法について, 遠心分離法と粉体層 の引張破断法を中心に若干の解説を行なった。測定方 法にはまだまだいろいろな原理のものが考光られるで あららし，またここで述べた方法についてもさらに適 切な測定手順や操作方法, あるいは装置設計の改良が 考えられるであろう。なにしろここで述べた方法は世 界的にみても本格的な研究がはじめられてからまだ 10 年になっていないし，わが国で研究がはじめられてか らもまだ 5 年とたっていないのである。まだ確立した 測定方法といえる段階にないのは当然である．したが ってこの小文は粉体物性測定法の手引きといらょり， いかにこの分野での測定方法に関して, これから研究 すべきテーマが数多くころがっているかを示したもの のつもりである.とくに若い研究者がこの方面の材料 研究に興味をもたれることを心から望む次第である。

\section{参 考 文 献}

1) Zimon, A.D., Adhesion of Dust and Powder, (Trans. by M. Corn) Plenum Press., p. 1 (1969).

2) 神保元二, 薬剂学, 30 (No.1), 1 (1970).

3）篠原邦夫, 小林 仁, 後藤圭司, 田中達夫, 粉体工学研 究会誌， 2, 352 (1965). 
4) 林平三郎, 見奈美秀蔵, 薬学雑誌, 84, 229 (1963).

5）野上 寿, 仲井由宣, 杉原正泰, 薬剤学, 24, 103 (1964).

6) 種谷真一, 応用物理, 33,887 (1964).

7）鈴木照麿, 農業技術研究所報告, C, No. 3, p. 98 (1953).

8) 石井義男, 赤柴健夫, 西村 茂, 小川正和, 農薬生産技 術, No.2, p.9 (1960).

9) 松井堯政, 粉体工学, 1, 598 (1964).

10）疋田 強，工業火薬協会誌，10, 143 (1950).

11）青木 大, 福田友昭, 薬剤学, 27, 103 (1967).

12) 横山藤平, 浦山 清, 粉体工学研究会誌, 6, 264 (1969).

13) Krupp, H., Advances in Colloid and Interface Science, 1 (No. 2), 113 (1967).

14) Corn, M., J. Air Poll. Control Assoc., 11, 566 (1961).

15) Schubert, H., Chemie-Ing. -Techn., 40, 745 (1968).

16）浅川貞雄, 神保元二, 材料, 16, 358 (1967).

17) 神保元二, ケミカル・エンジニヤリング, 13 (No.7), 31 (1968).
18）Zimon, A. D., 前掲書, p. 93.

19) Zimon, A. D., 前掲書, p. 10.

20) Corn, M., and F. Stein, Amer. Ind. Hgg. Assoc. J., July-Aug., p 325 (1965).

21) Löffler, F., Staub, 26, 274 (1966).

22) Rumpf, H., and E. Turba, Ber. Dtsch. Keram. Ges., 4178 (1964); “Agglomeration” ed. by Knepper, W. A., (John Wiley, 1962).

23) Ashton, M.D., D.C.H. Cheng, R. Farley, and F. H. H. Valentin, Rheological Acta, 4206 (1965).

24) Farley, R., and F.H.H. Valentin, Trans. Instn. Chem. Engrs., 43, 193 (1965).

25）神保元二, 浅川貞雄, 兽我尚人, 材料, 17, 540 (1968).

26) Shotton, E., and N. Harb, J. Pharm. Pharmacol., 18, 175 (1965).

27) 中島裕夫, 後藤圭司, 田中達夫, 化学工学, $\mathbf{3 0}, 946$ (1966). 